\title{
LIFETIME EARNINGS AND PHYSICIANS' CHOICE OF SPECIALTY
}

\author{
FRANK A. SLOAN
}

$\mathrm{T}$ THERE has been much discussion in the health services field about trends, since World War II, toward physician specialization. The gradual disappearance of the "family physician" has been observed widely and generally has been viewed as undesirable. Several methods for alleviating the problem have been suggested by the medical profession, such as instituting programs in family practice at the graduate level. Income incentives also have been sug. gested.

The objective of this study is to determine whether lifetime earnings in various specialties influence physicians' choice of field. If income does affect these choices, what is the magnitude of

\footnotetext{
The preference of medical students for spe. cialties over general practice and their choices of specialties are not explained by income differences in the various branches of medicine, according to the findings of this study. An examination of lifetime earnings in general practice and in specialties reveals no sys. tematic relationship to the future physician's choice of fields.

Frank A. Sloan is in the Economics Department, Rand Corporation. He is indebted to Harvard colleagues John Dunlop, Ralph Berry, Martin Feldstein, and Joseph Newhouse for a number of useful comments and to the U.S. Public Health Service for fellowship support. The calculations, presented in Table 1, were performed under a grant from the U.S. Public Health Service, Division of Nursing, "Returns on Investments in Training for Nurses and Physicians" (NU-00277.01), awarded to Donald Yett, Director, Human Resources Research Center, University of Southern California,-EDrroR
}

the supply response? Although income payments to practicing physicians in certain specialties thought to be "shortage" fields may be a politically infeasible policy instrument for influencing specialty choice, increases in residents' salaries could have some appeal for legislators. The effectiveness of both policies is evaluated in this article.

Estimates of lifetime earnings differentials between specialties and general practice are presented. These income differentials do not explain why virtu. ally all medical-school graduates enter residency programs. It is possible, nevertheless, that choices among particular specialties may reflect interspecialty in. come differences. Regression equations measuring the supply response to income in several specialties are presented. The results indicate that income payments to practicing physicians and stipends to residents in graduate medical education programs would have only a small effect on choice of field. Finally, possible deficiencies and extensions of the analysis are examined.

\section{Comparisons of Specialty and General Practice Earnings}

To determine whether the trend to. ward specialization reflects income incentives, calculations were made of the present values and internal rates of return to specialty training, based on 
Table 1. Returns to Investments in Training in Selected Specialties, 1955, 1959, and 1965.

\begin{tabular}{|c|c|c|c|c|c|c|c|c|c|c|}
\hline Year & $\begin{array}{c}\text { Discount } \\
\text { Rate } \\
\text { (percent) }\end{array}$ & $\begin{array}{l}\text { Anesthe- } \\
\text { siology }\end{array}$ & $\begin{array}{l}\text { General } \\
\text { Surgery }\end{array}$ & $\begin{array}{l}\text { Internal } \\
\text { Medicine }\end{array}$ & $\begin{array}{l}\text { Obstetrics- } \\
\text { Gynecology }\end{array}$ & $\begin{array}{c}\text { Ophthal- } \\
\text { mology }\end{array}$ & $\begin{array}{c}\text { Orthopedic } \\
\text { Surgery }\end{array}$ & $\begin{array}{c}\text { Pedia- } \\
\text { trics }\end{array}$ & $\begin{array}{c}\text { Psychia- } \\
\text { try }\end{array}$ & $\begin{array}{c}\text { Radiol- } \\
\text { ogy }\end{array}$ \\
\hline \multicolumn{11}{|c|}{ Present Values of Earnings* } \\
\hline $1955 \ldots$ & $\begin{array}{r}5.0 \\
10.0\end{array}$ & $\begin{array}{l}\text { N.A. } \\
\text { N.A. }\end{array}$ & $\begin{array}{r}9,898 \\
-15,250\end{array}$ & $\begin{array}{l}-36,832 \\
-30,856\end{array}$ & $\begin{array}{r}10,866 \\
-11,156\end{array}$ & $\begin{array}{l}\text { N.A. } \\
\text { N.A. }\end{array}$ & $\begin{array}{l}\text { N.A. } \\
\text { N.A. }\end{array}$ & $\begin{array}{l}-25,368 \\
-23,083\end{array}$ & $\begin{array}{r}4,726 \\
-11,535\end{array}$ & $\begin{array}{l}\text { N.A. } \\
\text { N.A. }\end{array}$ \\
\hline $1959 \ldots$ & $\begin{array}{r}5.0 \\
10.0\end{array}$ & $\begin{array}{l}\text { N.A. } \\
\text { N.A. }\end{array}$ & $\begin{array}{r}16,668 \\
-12,489\end{array}$ & $\begin{array}{l}-33,584 \\
-34,471\end{array}$ & $\begin{array}{r}8,735 \\
-9,313\end{array}$ & $\begin{array}{l}\text { N.A. } \\
\text { N.A. }\end{array}$ & $\begin{array}{l}\text { N.A. } \\
\text { N.A. }\end{array}$ & $\begin{array}{l}-18,403 \\
-16,918\end{array}$ & $\begin{array}{l}\text { N.A. } \\
\text { N.A. }\end{array}$ & $\begin{array}{l}\text { N.A. } \\
\text { N.A. }\end{array}$ \\
\hline $1965 \ldots$ & $\begin{array}{r}5.0 \\
10.0\end{array}$ & $\begin{array}{r}26,464 \\
158\end{array}$ & $\begin{array}{r}3,250 \\
-26,390\end{array}$ & $\begin{array}{l}-29,321 \\
-36,688\end{array}$ & $\begin{array}{r}-1,279 \\
-25,617\end{array}$ & $\begin{array}{l}67,937 \\
11,763\end{array}$ & $\begin{array}{r}167,599 \\
23,519\end{array}$ & $\begin{array}{l}-36,298 \\
-33,873\end{array}$ & $\begin{array}{r}-8,662 \\
-25,674\end{array}$ & $\begin{array}{r}115,107 \\
31,703\end{array}$ \\
\hline \multicolumn{11}{|c|}{ Internal Rates of Return $\dagger$} \\
\hline $\begin{array}{l}1955 \ldots \\
1959 \ldots \\
1965 \ldots\end{array}$ & & $\begin{array}{l}\text { N.A. } \\
\text { N.A. } \\
10.0\end{array}$ & $\begin{array}{l}5.7 \\
7.1 \\
5.2\end{array}$ & $\frac{-}{1.5}$ & $\begin{array}{l}6.7 \\
6.8 \\
4.8\end{array}$ & $\begin{array}{l}\text { N.A. } \\
\text { N.A. } \\
12.4\end{array}$ & $\begin{array}{l}\text { N.A. } \\
\text { N.A. } \\
13.8\end{array}$ & $\frac{-}{-}$ & $\begin{array}{c}5.9 \\
\text { N.A. } \\
3.9\end{array}$ & $\begin{array}{l}\text { N.A. } \\
\text { N.A. } \\
16.1\end{array}$ \\
\hline
\end{tabular}

*Deflated by the Consumer Price Index $(1957-1959=100)$. N.A. signifies that data are not available for the calculation.

- indicates that the internal rate of return is negative.

physicians' lifetime earnings differences between specialties and general practice. The same techniques sometimes are used to evaluate the net profitability of investment projects involving physical capital. In most studies of returns to investment in human capital, the return and cost streams do not represent the longitudinal experience of individuals with specified amounts of training; rather, these streams are cross-sectional composites of the earnings of individuals of different ages with a given quantity of formal education, recorded in a particular year.

Table 1 contains the present values and internal rates of return from investments in various types of specialty training for the years 1955, 1959, and 1965. The present-value calculations are differences in specialty and general practice earnings, discounted at either 5 or 10 percent. The internal rate of return is the discount rate which makes the present value of lifetime earnings in a specialty equal to the present value of earnings in general practice. For example, in Table 1 , the difference be tween general surgeon and general practitioner lifetime earnings in 1955, discounted at 5 percent, is positive; however, at 10 percent, it is negative. At some point between 5 and 10 percent, the two discounted income streams are equal. The 1955 internal rate of return for general surgery indicates that they are equal at 5.7 percent. $^{1}$

\footnotetext{
'Values of specialty training in various fields for the years 1955, 1959, and 1965 are calculated from reported earnings in private independent practice in Medical Economics and stipend data from education volumes of the Journal of the American Medical Association and the Hos. pital Physician. Statistics on salaries in the military are found in the Official Army Register, Adjutant General's Office, and the Hospital Physician, and survivor rates in annual'volumes of Vital Statistics of the United States, United States Public Health Service, Length of residency is the requirement of the certifying board for board certification in a specialty.

Since Medical Economics earnings data are available by experience rather than age cate-
} 


\section{PHYSICIANS' CHOICE OF SPECIALTY}

In many cases the earnings differentials are not consistent with the tendency of recent medical-school graduates to specialize. Several aspects of Table 1 are worth noting. First, the present values and internal rates of return are low in several specialties. For example, the present value of an investment in pediatrics is negative in 1955 , 1959, and 1965. Likewise, the present value of an investment in internal medicine is negative in 1955 and 1959 , and is virtually zero in 1965. Second, both present values and internal rates are generally invariant with respect to time. A decline in relative earnings of psychiatrists and obstetricians is evident, but such trends are minor. Third, there is substantial variation in returns among specialties; for example, there is a large difference among earnings in pediatrics and internal medicine and radiology in 1965. The returns from an investment in four years of medical school and an internship are substantially higher than those accruing to the medical-school graduate who specializes. The internal rate of return from an investment in general practice, as Table 2 shows, has varied from 23.7 to 29.1. Earnings of general practitioners are much higher than those of male college graduates. ${ }^{2}$

gories, the residency is assumed to begin at age 27 , followed by 2 years of military service or its equivalent, and finally entrance into selfemployed practice. As the income data are in experience categories, I interpolate linearly to smooth what would otherwise be a series of discrete steps in earnings. Income is assumed to terminate at age 65 . Net returns in each year are multiplied by a survivor rate which is the probability that a 27 -year old will realize the returns associated with a particular age.

${ }^{2}$ The calculations in Table 2 are based on the assumption that earnings begin at age 22 and terminate at age 65 . The return stream is composed of income received during medical school, internship salary, earnings in military service (assumed to be two years), and income of self-employed general practitioners. Income
Table 2. Returns to Four Years of Medical School and an Internship.

\begin{tabular}{|c|c|c|c|}
\hline $\begin{array}{c}\text { Discount Rate } \\
\text { (percent) }\end{array}$ & 1955 & 1959 & 1965 \\
\hline \multicolumn{4}{|c|}{ Present Values of Earnings* } \\
\hline $0.0 \ldots \ldots \ldots$ & 216,083 & 288,667 & 358,683 \\
\hline $5.0 \ldots \ldots \ldots$ & 79,086 & 102,810 & 127,224 \\
\hline $10.0 \ldots \ldots \ldots$ & 33,542 & 39,841 & 50,065 \\
\hline $15.0 \ldots \ldots \ldots$ & 15,024 & 15,350 & 19,437 \\
\hline \multicolumn{4}{|c|}{ Internal Rates of Return } \\
\hline & 29.1 & 23.7 & 24.1 \\
\hline
\end{tabular}

If medical-school graduates based decisions on past earnings, it would be possible to observe low current returns and large numbers of individuals specializing. However, even if a lag were appropriate, the tendency to specialize would remain unexplained. Less than 2 percent of current graduates are now choosing a career in general practice, and it is known that returns to specialization have been low in several specialty fields since $1955 .^{3}$ One may suppose the lag to be at most three or five years. It is thus unlikely that the decision to specialize reflects high pre-1955 lifetime earnings, for which no measurements are available.

Investment considerations of the type captured by the present value and rate

during medical school is assumed to be one fourth that of male college graduates of the same age. The internship salary is from the Journal of the American Medical Association. Earnings in military service are from the official Army Register. Income of general practitioners is from Medical Economics. The cost stream includes tuition and fec information from education volumes of the Journal of the American Medical Association and age-specific median income of white male college graduates from the Census Bureau.

${ }^{8}$ The 2 percent estimate is reported in the Report of the National Advisory Commission on Health Manpower (Washington: G.P.O., 1967), p. 14. 


\section{INDUSTRIAL AND LABOR RELATIONS REVIEW}

of return calculation are not necessarily unimportant in explaining the tendency to specialize. It is possible that the above computations do not account for the relevant incentives. For example, the income elasticity of demand for general practitioners' services is low. Although no precise estimate can be cited, more affluent consumers of medical care do seem to use specialists more frequently. Forecasting greater affluence for society at large, medical-school graduates may forsee decreases in relative earnings of general practitioners. Moreover, general practitioners may find it increasingly difficult to secure hospital privileges. Many may fear possible technological obsolescence of the general practitioner.

\section{Influence of Earnings on Choices Among Specialties}

The aforementioned evidence indicated that lifetime-earnings estimates do not provide a good explanation of the tendency of medical-school graduates to specialize. In only four of the nine specialties examined are there monetary incentives associated with an investment in a specialty. But do these graduates respond to income differences in choosing among specialties? If they do, what is the impact of earnings differentials on these decisions? Could subsidies to specialists in "shortage" fields be used as an effective policy instrument? Might stipends to residents be an effective policy? The answers to these questions depend on the size of the coefficient of the lifetime-earnings variable of the regression equation described below. Data on several specialties for three years will be used to derive the coeffcient estimates. ${ }^{4}$

\footnotetext{
-At most, 9 observations are included in a single cross section. The paucity of data in
}

Two dependent variables are tested: the number of residents in a particular specialty in a given year who are graduates of American and Canadian medical schools, and the number of residents in a specialty divided by the number of residencies offered in that field in a given year. ${ }^{5}$

The present value of lifetime earnings in various fields in 1955, 1959, and 1965 is the first independent variable. Equations which include the present values of lifetime earnings discounted at 5 and 10 percent are used alternatively to investigate the sensitivity of the income coefficient estimate to interest rate assumptions.

As indicated in Table l, some of the present values are negative at discount rates of 5 or 10 percent. The model is estimated in both linear and logarithmic form; logarithms of zero or negative numbers cannot be taken. Thus, a constant is added to each of the present values to insure each observation will exceed zero. The purpose of this algebraic transformation is to avoid losing a large number of observations when the coefficients are obtained from a model in the logarithmic form. ${ }^{\circ}$ Earnings are lagged one year behind the dependent variable.?

a single cross section precludes the use of statistical tests for changes in the relationships over time.

'Source of data on the number of residents and positions in residency programs is annual graduate education volumes of the Journal of the American Medical Association.

oWhen a constant is added to lifetime earn. ings, the interpretation of the log form coefficients changes. For a discussion of this point, see R. G. D. Allen, Mathematical Analysis for Economists (New York: St. Martin's Press, 1966), p. 253.

'Earnings of several years in the past may affect specialty decisions. Unfortunately, existing data do not allow the researcher to de termine the effects of lagged income precisely. 


\section{PHYSICIANS' CHOICE OF SPECIALTY}

Two other independent variables are included in the equation: the number of residencies in the specialty and total foreign graduates. There are three reasons for including the number of residencies in the equation. First, some fields are more general and provide a broad base from which further specialization is possible. Second, some special. ties are larger because they afford more opportunities to practice. Third, the number of positions in residency programs in a specialty places a limitation on the number of medical-school graduates who can enter the field. If the number of positions increase, so may entrants. Although the aggregate numbers of residencies have exceeded the total number of residents in all fields, there typically may be no vacancies in prestigious hospitals in some fields. Rather than forego the opportunity of enrolling in a program in a preferred hospital, some medical-school graduates may enter a specialty which is not their first choice. ${ }^{8}$ Unfortunately, the available data do not allow one to evaluate or disentangle these three influences.

The third independent variable is the total number of foreign graduates in a given year who are enrolled in domestic residency programs. The growth of residencies has exceeded the growth of the pool of potential American and Canadian residents, largely because a relaxation

\footnotetext{
${ }^{8}$ The variable is considered to be exogenous. It conceivably could be treated as endogenous; particularly if there is a cost to the hospital of maintaining unfilled places in its residency programs. There may be losses in terms of prestige and hence in the institution's ability to attract high quality graduates. Since places in residency programs are announced before the graduate's application, the variable may be considered predetermined endogenous if un. filled residencies affect the number of residencies offered in the following year. Otherwise, it is exogenous. In either case ordinary least squares is an appropriate estimation technique.
}

of immigration restrictions has allowed large numbers of graduates of foreign medical schools to enter internship and residency programs in the United States. Hospitals have offered more internships and residencies than they would have if greater immigration restrictions had existed. It is necessary to include a variable to account for the trend in the ratio of residents to positions in residency programs to avoid biases in the coefficient estimates. In using this variable, it is assumed that the impact of the availability of a foreign graduate pool is directly proportional to the total num. ber of foreign graduates in a given year who are enrolled in domestic residency programs. The total foreign graduates variable is included as an explanatory variable for an econometric reason: to remove a time-varying component from the error term. ${ }^{\circ}$

\section{Empirical Results}

Table 3 contains the coefficient estimates. The lifetime-earnings variable is significant at the 5 percent level or better in both linear and logarithmic forms. The discount rate influences the coeffcient estimate in a plausible manner but does not affect goodness of fit. As lifetime earnings at 10 percent are smaller than lifetime earnings at 5 percent, the coefficient estimate of the former is larger to compensate for the smaller values of incomes, discounted at 10 percent. There thus seems to be little reason for concern about the appropriateness of a particular discount rate. Although earnings affect specialty decisions, the impact is small. Referring to the lifetime-earnings coefficient esti-

\footnotetext{
OSource of foreign graduate data: annual graduate medical education volumes of the Journal of the American Medical Association.
} 
Table 3. Empirical Results: The Effect of Lifetime Earnings and Specialty Choice.

1. Residents ${ }^{*} t^{*}$

$=4388.2+0.0034$ Lifetime Earnings $(5 \%)_{i t-1}$ $3.171^{b}$

+0.6327 Residencies $_{i t}-0.6193$ Foreign Graduatest. $26.574^{8} \quad 3.151^{8}$

$R^{2}=0.98 \quad R^{2}(C)=0.98$

2. Residents $i t=3687.0+0.0075$ Lifetime Earnings $(10 \%)_{i t-1}$ $2.818^{b}$

+0.6427 Residencies $_{i t}-0.5056$ Foreign Graduates . $^{\prime}$ $23.736^{\mathrm{b}} \quad 2.929^{\mathrm{b}}$

$R^{2}=0.98 \quad R^{2}(C)=0.98$

3. $\log _{e}$ Residents $_{i l}=-1.1099+0.2045 \log _{0}$ Lifetime Earnings $(5 \%)_{i t-1}$ $2.580^{a}$

$+0.9468 \log _{e}$ Residencies $_{i t}-0.1422 \log _{\odot}$ Foreign Graduates $t$. $18.695^{b} \quad 1.623$

$R^{2}=0.97 \quad R^{2}(C)=0.96$

4. $\log _{e}$ Residents $_{i t}=-3.5250+0.3414 \log _{e}$ Lifetime Earnings $(10 \%)_{i t-1}$ $2.509^{\circ}$

$+0.9771 \log _{\ominus}$ Residencies $_{i t}-0.0664 \log _{\ominus}$ Foreign Graduates . $16.937^{\circ} \quad 0.342$

$R^{2}=0.97 \quad R^{2}(C)=0.96$

5. Residents $_{i t} /$ Residencies $_{i l}=1.521+0.0000014$ Lifetime Earnings $(5 \%)_{i t-1}$ $3.531^{\mathrm{b}}$

-0.0123 Foreign Graduates!.

$-1.173$

$R^{2}=0.47 \quad R^{2}(C)=0.41$

* $i$ stands for the specialty; $t$ for time. Numbers below the coefficients are $t$-values. The letter " $a$ " signifies that the coefficient is significant at the $5 \%$ level. " $b$ " means the coefficient is significant at the $1 \%$ level (two-tail test). $R^{2}(C)$ is the $R^{2}$ corrected for degrees of freedom.

mate in equation 1, a $\$ 10,000$ increase in lifetime earnings would attract thirtyfour medical-school graduates to a particular specialty. In equations 1 through 4 , the number of residencies explains most of the variation in the dependent variable. Equation 5 indicates that a reasonably good fit can be obtained when residency is not an independent variable.

Elasticities based on the lifetimeearnings coefficient of equations 1 and 2 of Table 3 are presented in Table 4. Each elasticity is taken at the actual value of the two variables. The highest elasticity is 0.28 ; in many cases it is near zero. Therefore, although earnings do have an influence on career choice, large changes in relative earnings would be required to effect very noticeable changes in specialty entry patterns. ${ }^{10}$

Subsidies to practicing physicians probably would be infeasible for political reasons, even if the elasticities were high. Increases in stipends to residents would be a much more politically palatable recommendation. The regression equation results permit investigation of the responsiveness of medicalschool graduate specialty decisions to changes in stipends. For evaluating the effects of stipend increases on specialty decisions it is useful to construct an clasticity which expresses the responsive.

${ }^{10}$ Elasticities based on lifetime earnings co. efficients of equations 3 and 4 have been calcu. lated, but are not presented here. They are almost identical to those in Table 4. 
Table 4. Estimates of the Impact of Lifetime Earnings on Specialty Choice.

\begin{tabular}{|c|c|c|c|c|}
\hline Specialty and $Y_{e a r}$ & $\begin{array}{l}\text { Number of } \\
\text { Residentsit }\end{array}$ & $\begin{array}{c}\text { Lifetime } \\
\text { Earningsit-1 }\end{array}$ & 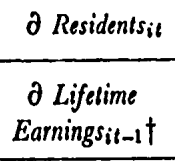 & $\begin{array}{l}\text { Residents- } \\
\text { Lifetime } \\
\text { Earnings } \\
\text { Elasticity }\end{array}$ \\
\hline \multicolumn{5}{|c|}{5 Percent Discount Rate } \\
\hline General surgery $1956 \ldots \ldots \ldots \ldots$ & 4,137 & $\$ 9,898$ & 0.0034 & 0.0080 \\
\hline Obstetrics-gynecology $1956 \ldots . .$. & 1,749 & 10,866 & 0.0034 & 0.0209 \\
\hline Psychiatry 1956. . ........... & 1,768 & 4,726 & 0.0034 & 0.0090 \\
\hline General surgery $1960 \ldots \ldots \ldots$ & 3,938 & 16,669 & 0.0034 & 0.0141 \\
\hline Obstetrics-gynecology $1960 \ldots \ldots$. & 1,783 & 8,735 & 0.0034 & 0.0164 \\
\hline General surgery $1966 \ldots \ldots \ldots \ldots$ & 3,816 & 3,250 & 0.0034 & 0.0029 \\
\hline Ophthalmology $1966 \ldots \ldots \ldots$ & 1,029 & 67,937 & 0.0034 & 0.2218 \\
\hline Orthopedic surgery $1966 \ldots \ldots \ldots$ & 1,395 & 167,599 & 0.0034 & 0.2592 \\
\hline Radiology $1966 . . . \ldots \ldots \ldots$ & 1,406 & 115,107 & 0.0034 & 0.2751 \\
\hline \multicolumn{5}{|c|}{10 Percent Discount Rate } \\
\hline Ophthalmology $1966 \ldots \ldots \ldots \ldots$ & 1,029 & 11,763 & 0.0075 & 0.0087 \\
\hline Orthopedic surgery $1966 \ldots \ldots \ldots$ & 1,395 & 23,519 & 0.0075 & 0.1264 \\
\hline Radiology $1966 . . \ldots \ldots \ldots \ldots$ & 1,406 & 31,703 & 0.0075 & 0.1691 \\
\hline
\end{tabular}

*Deflated by Consumer Price Index $(1957-1959=100)$.

†0.0034 is the coefficient estimate of the lifetime earnings variable, equation 1, Table 3. 0.0075 is the estimate of the earnings variable, equation 2 of the same table.

ness of medical-school graduates to changes in stipends. This elasticity may be determined once the change in lifetime earnings arising from a change in stipends is calculated. The

percentage change in residents

percentage change in lifetime earnings

the residents.lifetime earnings elasticity, multiplied by the

percentage change in lifetime earnings percentage change in stipends

yields, with cancellation, the percentage change in residents percentage change in stipends the residents.stipends elasticity. The lifetime earnings-stipends elasticity may be calculated by assuming a percentage increase in resident stipends. For the purpose of calculating the residents-
Table 5. Estimates of the Effect on Specialty Choice of Stipends Awarded to Residents.

\begin{tabular}{|c|c|}
\hline Specially and Year & $\begin{array}{l}\text { Residents- } \\
\text { Stipends } \\
\text { Elasticity* }\end{array}$ \\
\hline \multicolumn{2}{|l|}{5 Percent Discount Rate } \\
\hline General surgery $1956 \ldots \ldots \ldots$ & 0.008 \\
\hline Obstetrics-gynecology $1956 \ldots \ldots$ & 0.015 \\
\hline Psychiatry $1956 \ldots \ldots \ldots \ldots$ & 0.014 \\
\hline General surgery $1960 \ldots \ldots \ldots$ & 0.093 \\
\hline Obstetrics-gynecology $1960 \ldots \ldots$ & 0.018 \\
\hline General surgery $1966 \ldots \ldots \ldots$. & 0.017 \\
\hline Ophthalmology $1966 \ldots \ldots \ldots \ldots$ & 0.041 \\
\hline Orthopedic surgery $1966 \ldots \ldots \ldots$ & 0.050 \\
\hline Radiology $1966 \ldots \ldots \ldots \ldots \ldots$ & 0.029 \\
\hline \multicolumn{2}{|l|}{10 Percent Discount Rate } \\
\hline Ophthalmology $1966 \ldots \ldots \ldots$ & 0.009 \\
\hline Orthopedic surgery $1966 \ldots \ldots$ & 0.086 \\
\hline Radiology $1966 \ldots . . \ldots \ldots \ldots$ & 0.062 \\
\hline
\end{tabular}

${ }^{*}$ As in Table 4, the coefficient estimate of the lifetime-earnings variable of equation 1 , Table 3 is used in the calculations.

stipends elasticities found in Table 5, a 100 percent increase is assumed. 


\section{INDUSTRIAL AND LABOR RELATIONS REVIEW}

In all cases the residents-stipends elasticities are quite small, indicating that increases in payments to residents in a particular specialty would not be a very effective policy instrument for inducing individuals to enter that field. It is quite plausible, however, that the measure of the stipend impact on specialty choice is an underestimate if medicalschool graduates are not able to borrow at the interest rate on which the calculations are based. If the cost of funds to residents is high, say, for example 15 or 20 percent, an increase in stipends will change lifetime earnings substantially, much more than if the rate is only 5 or 10 percent. Stipends will thus be a very important element in the decision to enter a particular specialty. As a test of the hypothesis that medical-school graduates can borrow only at high interest rates, two variables (one representing stipends to residents and the other, in. come of specialists in practice) were in. cluded separately in a regression equation. The results, not presented here, support the conclusion that stipends have only a minor effect on specialty choice. ${ }^{11}$

It should be emphasized these findings pertain to changes in returns to training in a particular field on a national level. A particular hospital which is able to raise resident salaries may be quite successful in attracting medical-school graduates to its program.

\section{Discussion of the Low Elasticity Estimates}

The elasticity calculations of the previous section indicate that neither subsi-

\footnotetext{
"See F. A. Sloan, "Economic Models of Physician Supply" (Ph.D. dissertation, Harvard University, 1968), pp. 215-222. These results in. dicate the residents-stipends elasticity is low, 0.15 at the highest.
}

dies to practicing physicians nor increases in stipends to residents in "shortage" fields would be useful policy instruments for attracting medical-school graduates to these areas. However, the low elasticity estimates may reflect fundamental weaknesses in the analysis. In this section two possible deficiencies will be investigated.

First, if medical-school graduates respond to income over a period of several years (specialist earnings in past as well as in recent periods), the earnings coefficients may be expected to be biased downward, leading to low elasticity estimates. Furthermore, the bias would be substantial if there were pronounced variation in a temporal sense in the income series. However, as Table 1 indicated, intertemporal variation is small in comparison with interspecialty variation. This provides some evidence that the downward bias, if.it exists at all, is not severe.

Second, rather than look to past or current behavior of earnings in various specialty fields alone, the medical-school graduate may place considerable emphasis on other indicators of future income performance. Certain fields may be characterized as excess supply specialties, and earnings may reflect this development only slowly. The decision maker may be just as likely to base his specialty decision on the number of job seekers relative to the number of job vacancies in a given field as on current income differentials. ${ }^{12}$ For example, earnings in pediatrics may be expected to rise relatively because job vacancies currently far exceed job seekers. In general surgery, there are more job seekers than vacancies.

${ }^{12}$ Since 1965 such data have been published in the annual education volume of the Journal of the American Medical Association. 
A final regression equation, based on a single cross section, is developed to utilize information on job seekers and job vacancies which is available only for recent years. It contains three explanatory variables: (1) lifetime earnings, dis. counted at 5 percent; (2) a series which is the number of specialists in a given field seeking employment divided by the number of vacancies known to the American Medical Association in that field in the years 1964 through 1966 (hereafter relerred to as excess supply); and (3) a measure of physician dissatisfaction with their respective specialties. The third variable is a proxy for the consumption benefits associated with particular fields. As in the decision to specialize, investment in a particular type of specialty training is likely to reflect consumption as well as investment benefits. The latter are represented in large part by the present value and in. ternal rate-of.return calculations. ${ }^{13}$ Consumption benefits include the distribution of hours, intellectual stimulation, depth of contact with patients, efficacy of treatment, and prestige. Physician satisfaction with his field is likely to reflect these factors. The dissatisfaction series is constructed by multiplying by two the percentage of physicians in a specialty who said in a 1966 survey they were "somewhat dissatisfied" and multiplying by four the percentage who were "dissatisfied" and adding the two numbers. ${ }^{14}$ Assigning weights to these percentages is, of course, arbitrary. Furthermore, as the survey was not designed for

\footnotetext{
${ }^{18}$ Consumption benefits are excluded from the equations presented in Table 3 because no consistent data on physician appraisals of their specialties are available for all the years covered in the regressions.

"Source of data on physician satisfaction with specialty: Medical Economics, Oct. 3, 1966, pp. $158-178$.
}

purposes of this study, physicians' ap. praisals are likely to reflect earnings in part. It would be more desirable if the income component were confined to the lifetime-earnings variable.

$$
\begin{aligned}
& \log _{\odot} \text { Residents }=1.945 \\
& -0.0894 \log _{\odot} \text { Lifetime Earnings }(5 \%) \\
& -0.3913 \\
& -0.1648 \log _{e} \text { Excess Supply } \\
& -1.1337 \\
& -0.2801 \log _{\ominus} \text { Dissatisfaction. } \\
& -2.5581^{\circ} \\
& R^{2}=0.63 \quad R^{2}(C)=0.33
\end{aligned}
$$$$
{ }^{a} \text { significant at the } 5 \text { percent level. }
$$

Dissatisfaction, essentially a consumption variable, outperforms the other two. Excess supply has the correct sign, and the coefficient estimate exceeds its standard error. This provides some further evidence (inconclusive because of so few observations) that pecuniary considerations do have some influence on specialty decisions. This result also may indicate the medical-school graduate looks beyond current income in assessing returns to investments in specialty training in alternative fields. Lifetime earnings, which performed well above, do very poorly in this regression, probably because of the paucity of observations. Clearly, it will be appropriate, as more data become available, to reassess the low elasticity estimates presented in this article.

Further research also should explore possible interactions between the number of residencies offered, returns to investments in specialty training, and the physician's choice of specialty. The elasticity calculations, presented above, reflect the change in the number of physicians entering a particular field, holding the number of positions in 
graduate medical education programs constant. For policy purposes, it would be interesting to know the effect of pecuniary incentives if the number of residencies were not held constant.

\section{Conclusion}

The objective of this investigation has been to study medical-school graduates' responses to lifetime earnings. No systematic relationship has been detected between virtually unanimous decisions of recent medical-school graduates against careers in general practice and specialty-general practice earnings differences. However, pecuniary considerations still may partially explain the ten. dency to specialize even though the evidence is missing. The medical-school graduate may be able to see reasons for a future decline in relative earnings, not reflected by past and current income data. Also this author has sought to determine whether lifetime earnings have an effect on the choice of specialty, given the medical-school graduate has decided to enter a hospital-residency program of some type. The coefficient of the income variable often is significant at the 1 percent level in regression equations which are developed to measure the supply response. Although the hypothesis of no relationship between specialty choice and earnings is rejected statistically, the estimated impact of lifetime income on these decisions is small. Likewise, increases in residency stipends may be expected to exert little influence on specialty choice. As in the decision to enter a specialty or general practice, earnings information of the type considered in this study may be only one of several indicators of monetary benefits to be derived from an investment in a particular type of specialty training. The number of physicians seeking employment relative to the number of vacancies in a particular specialty may be another. Finally, although this article has concentrated on investment aspects, consumption benefits (such as intellectual stimulation and prestige) undoubtedly have a role in physician-specialty decisions. 